\title{
Sustainable development of economic systems on the basis of innovative processes
}

\author{
Alexey Ilyukhin*, Evgeny Kislitsyn, and Svetlana Ilyukhina
}

Ural State University of Economics, 8 Marta/Narodnoy Voli Str., 62/45, 620144 Ekaterinburg, Russia

\begin{abstract}
The social and economic processes resulting from the COVID19 pandemic are a new global factor that highlights setting out conditions for sustainable development of economic systems. The authors propose a hypothesis that a stable growth rate of national economy is ensured by qualitative and systemic improvement of leading innovative indicators. Thus, the purpose of the paper is to study the dynamics of and correlation between indicators of innovative development of territorial and sectoral economies. The paper presents economic and statistical study of the volume of innovative products and performed services, funding of technological innovations; the creation and application of new technologies. To ensure representativity of the sample, the authors analyzed the leading performance indicators in Russian R\&D organizations from January to June 2020. The parameters of the analysis were the location in a federal district and a form of ownership. A direct correlation between R\&D costs and the average number of researchers has been revealed. Sustainable development of economic systems in a new economic reality is possible only with the application of effective methods of analyzing innovation costs, studying laws and factors of innovation development, forms of endogenous and exogenous technological exchange for all economic entities.
\end{abstract}

\section{Introduction}

According to the UN Commission on Sustainable Development, the main indicators of sustainable development are balanced and safe social, economic and spatial well-being, social development, and the formation of a competitive economy based on institutional economic freedom $[1,2]$. The solution of this range of tasks is possible only if the development is based on the innovative institutional environment of the economic system of society [3]. The social and economic processes resulting from the COVID-19 pandemic are a new global factor that highlights setting out conditions for sustainable development of economic systems. Under the current conditions sustainable development can be ensured on the basis of innovative factors only, and the losses of society caused by the global pandemic should be considered as an additional challenge and a new restrictive format [4].

The issues of sustainable innovative development and economic growth are being discussed in the international and Russian literature. The discussion is built around global

\footnotetext{
*Corresponding authoriluhiaa@usue.ru
} 
economic trends and new industrialization of the Russian economy [5; 6]. Some authors focus on regional economy $[7 ; 8 ; 9]$ and trends affecting the place of rural areas in regional development $[10 ; 11]$. All scholars agree that accumulated experience and innovative factors provide the basis for sustainable development of economic systems.

Sustainable development at the national level is directly linked to innovative activities of economic entities in a sector or a region. The development and implementation of innovative ideas is the main avenue of growth for socio-economic systems. This has become a matter of priority for the Russian economy, as it sets out conditions for innovation transition.

The basis of sustainable innovative development of society is measured by how deep new technologies are integrated in the sphere of social reproduction; a number of research and production complexes; creation of new hybrid research-centered communities; effective public funding; as well as how the $R \& D$ issues are approached in a region/territory These factors should be translated into innovation statistics and reflect the dynamics of innovation activities not only in the field of industrial production and information technologies, but also in the 'creative' areas, such as education and science, based on world empirical and potential experience [12].

The authors propose a hypothesis that a stable growth rate of the national economy is ensured by the qualitative and systemic improvement of leading innovative indicators of territorial and sectoral economies. Therefore, the purpose of the paper is to study the dynamics of and correlation between indicators of innovative development of territorial and sectoral economies.

\section{Materials and Methods}

The scope of innovation-driven growth of economic systems is analyzed by applying a science-based analytical method to identify the reference points of active innovative processes. In order to adequately and comprehensively assess the real potential and level of innovative development of economic systems, it is essential to analyze: the volume of innovative products and performed services, funding of technological innovations; the creation and application of new technologies. At the same time, it was taken into account that by international statistics standards, innovative products are understood not only as brand new, but also include those that have undergone changes for the last three years. The financial resources, required for the innovation activities of the territorial and sectoral economic systems, are planned by grouping the expenditure on innovation types and sources of financing.

To ensure representativity of the sample, we analyzed the leading performance indicators in Russian R\&D organizations from January to June 2020. The parameters of the analysis were the location in a federal district and a form of ownership.

\section{Results and Discussion}

In Russia, from January to June 2020, the average salary per employee in an R\&D organization was 381.22 thou rubles; with the highest - in municipal organizations (1864.46 thou rubles); the lowest - in government agencies in charge of agricultural finance (161.44 thou rubles).

The average $R \& D$ costs per organization accounted for 134363.96 thou rubles, with the highest costs incurred in the Federal Service for Technical and Export Control of Russia (1 268 946. 8 thou rubles). The proportion of internal R\&D costs was 1083016.63 thou rubles. The lowest R\&D costs were recorded in regional and 
local public associations (1 919.16 thou rubles (external) and 1537,86 thou rubles (internal). On average, in the Russian Federation, one organization spent 115693.27 thou rubles on $R \& D$.

Internal operating costs (less depreciation) per organization averaged out at 109 756. 29 thou rubles, ranging from the highest costs in the Federal Service for Technical and Export Control (1 081395.68 thou rubles) to the lowest costs in regional and local public associations (1 536.15 thou rubles).

The costs associated with the payment to researchers per organization amounted to 49001.56 thou rubles. The highest amount spent (350 570.04 thou rubles) was recorded in State Atomic Energy Corporation Rosatom (hereinafter: Rosatom). The lowest amount (354.87 thou rubles) was paid in regional and local public associations. The average amount per organization stood at 51953.28 thou rubles.

Capital expenditure per organization averaged out at 5936.97 thou rubles. The maximum capital expenditure was used in Rosatom (137 048.76 thou rubles). Local government health care agencies spent the lowest amount (26.19 thou rubles).

External R\&D costs per organization accounted for 18670.69 thou rubles. The Federal Service for Technical and Export Control incurred the highest costs (185 930.17 thou rubles), while the Ministry of Culture of the Russian Federation showed the lowest spending (32.23 thou rubles).

The average allocation for fixed assets depreciation per organization was 15053.67 thou rubles. The highest charges were carried by the Federal Service for Technical and Export Control (106 634.12 thou rubles), the lowest - by regional and local public associations (45.04 thou rubles).

Internal R\&D costs from the federal budget resources per organization accounted for 54 006.29 thou rubles. Rosatom incurred the highest costs (559 294.44 thou rubles), government agencies bore the lowest (542.20 thou rubles).

The analysis of the tables of the All-Russian Classifier of Political Subdivisions showed that the highest payroll costs per employee were incurred in the Far Eastern Federal District, the lowest - in the North Caucasus Federal District. The highest R\&D costs were in the Central Federal District, the lowest - in the North Caucasus Federal District. A similar pattern of distribution was recorded for depreciation charges and internal R\&D costs from the federal budget resources.

The analysis of the legal entities of the Russian Federation revealed that the highest payroll costs per researcher were in Tyumenskaya Oblast, the lowest - in Ryazanskaya Oblast. Total R\&D costs were the highest in Nizhny Novgorod Oblast, and the lowest in Altai Republic. Depreciation charges on fixed assets were the highest in Tomskaya Oblast, the lowest - in Altai Republic. Internal R\&D costs from the federal budget resources were the highest in Nizhny Novgorod Oblast, the lowest - in Lipetskaya Oblast.

The analysis by a form of ownership indicated that the performance indicators of foreign $R \& D$ organizations are better than Russian ones. The payroll costs per researcher and $R \& D$ costs per organization are the lowest in religious associations. Municipalityowned organizations incured the highest payroll costs per researcher, and state-owned organizations incured the highest $R \& D$ costs per organization. Internal $R \& D$ costs and $\mathrm{R} \& \mathrm{D}$ costs from the federal budget resources per organization were minimal in organizations belonging to trade unions, and maximum - in state-owned organizations.

\section{Conclusions}

This paper studied the dependence of $R \& D$ costs on the average number of researchers. Several regression models were constructed for this purpose (Table 1). 
Table 1. Regression models of the dependence of R\&D costs on the average number of researchers

\begin{tabular}{|c|c|r|c|}
\hline Regression model & $\begin{array}{c}\text { Determination } \\
\text { coefficient }\end{array}$ & F-test & $\begin{array}{c}\text { Approximation } \\
\text { mean error, \% }\end{array}$ \\
\hline$\tilde{y}=-\mathbf{1 0 1 9 2 9 5 + 1 0 5 8 x}$ & 0.9933 & $\begin{array}{r}12527.4 \\
3\end{array}$ & 362 \\
\hline$\tilde{y}=469.14 x^{1.045}$ & 0.9278 & 1080.06 & 90 \\
\hline$\tilde{y}=-543339,04+924,73 x+0,00087 x^{2}$ & 0.9954 & $\begin{array}{r}18019.4 \\
5\end{array}$ & 192 \\
\hline
\end{tabular}

where $y$-total R\&D costs (thou rubles); $x$ - the average number of researchers (part-time employees and contractors excluded)

The correlation plot (Fig. 1) shows the evident relationship between the studied parameters. In our opinion, the best model was chosen for analyzing regression models, since the construction of the second-order polynomial, linear and power regression revealed the presence of significant approximation errors despite the calculated correlation and determination coefficients, which confirms the presence of a stable relationship and dependence between the studied parameters.

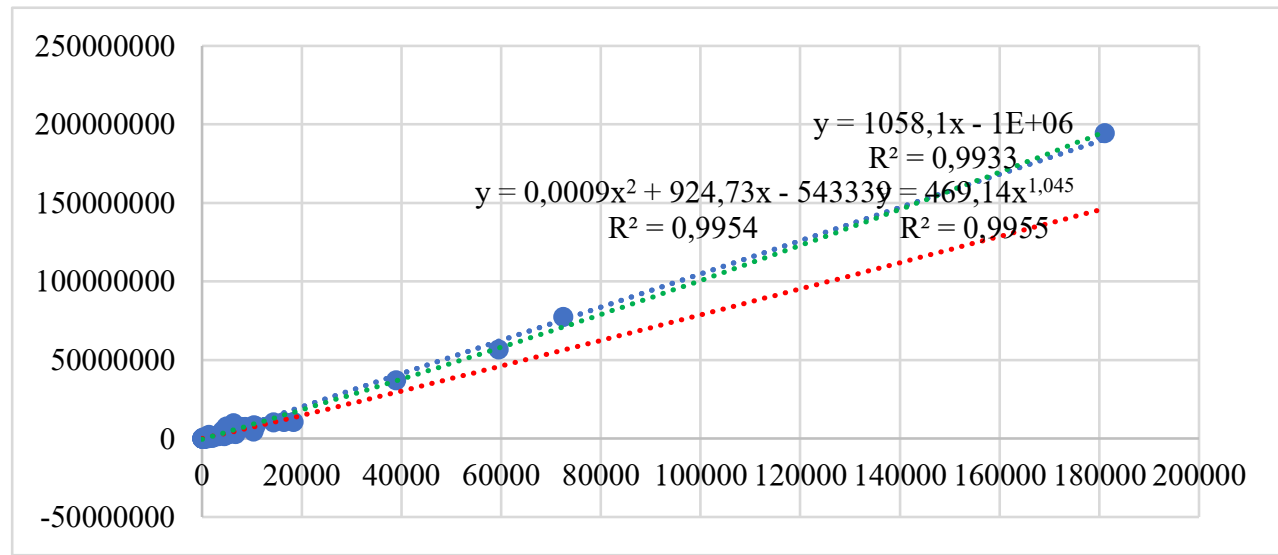

Fig. 1. Correlation plot of the dependence of $R \& D$ costs on the average number of researchers

If we take into account the mean approximation error, then no model gives the smallest discrepancy between the actual and theoretical data. At the same time, all regression models accurately reflect the original data. Preference can be given to the parabolic function, for which the values of the coefficient of determination and F-test are the largest.

The present study of the leading performance indicators of R\&D organizations from January to June 2020 by federal districts and forms of ownership has demonstrated a important impact of these factors on the outcome.

The obtained data have shown that the major financial support of innovative projects has been provided by R\&D organizations' own funds. At the same time, the innovation activity of primary economic systems has been constrained by objective and subjective factors, such as high risks, insufficient financial resources, poor in-house R\&D complex, lack of qualified personnel, and high transaction costs.

A direct correlation between $R \& D$ costs and the average number of researchers has been revealed. This is important for building effective incentive and remuneration schemes in R\&D organizations.

Sustainable development of economic systems in a new economic reality is possible only with the application of effective methods of analyzing innovation costs, studying laws 
and factors of innovation development, forms of endogenous and exogenous technological exchange for all economic entities.

\section{References}

1. Working list of indicators of the UN Commission on Sustainable Development. https://sustainabledevelopment.un.org/

2. D. H. Meadows, D. L. Meadows, J. Randers, W.W. Behrens III, The Limits To Growth. A Report For The Club Of Rome's Project On the Predicament Of Mankind (1972)

3. A. Ilyukhin, S. Ponomareva, S. Ilyukhina, E3S Web of Conferences 208, 03006 (2020)

4. Ilyukhin, A. A. Ilyukhina, S. V., Proceedings of the 9th International conference for science educators and teachers (2018)

5. S.D. Bodrunov, R.S. Grinberg, D.Ye. Sorokin, Economic revival of Russia, 1(35) (2013)

6. A.I. Tatarkin, Economic revival of Russia, 2(44) (2015)

7. Ya.P. Silin, E.G. Animitsa, J. of New Economy, 21(1) (2020)

8. Ya.P. Silin, E.G. Animitsa, N.V. Novikova, Economy of the region, 13(3) (2017)

9. Ya.P. Silin, E.G. Animitsa, N.V. Novikova, Economy of the region, 12(3) (2016)

10. Kristof V.A., Hornidge A.K. Rural development: Knowledge and expertise in governance, Wageningen Academic Publishers, Wageningen (2015)

11. Neil Ward \& David L. Brown. Regional Studies, 43(10), 1237 (2009)

12. Kislitsyn E., Gorodnichev V., E3S Web of Conferences. 1,03012 (2020) 